\title{
On the "Pleonastic" Usage of Complement Markers in Early Modern Greek
}

\author{
Eleni Karantzola* \\ University of the Aegean \\ karantzola@rhodes.aegean.gr \\ Konstantinos Sampanis \\ University of the Aegean \\ k.sampanis@rhodes.aegean.gr
}

\begin{abstract}
A syntactic feature that characterizes Early Modern Greek is the "pleonastic" usage of the complement conjunction óti or pos with the mood ("subjunctive") particle $n a$, as well as the co-presence of the complementisers óti and pos. These co-occurrences are ungrammatical in Modern Greek, while in vernacular Late Medieval and Early Modern Greek texts they are sufficiently attested. In this paper we record a large number of instantiations of the $\{$ óti / pos $\}+n a /$ óti + pos structures in order to trace the conditions of their occurrence; the examples come from extended prose texts of the 16th century as Kartanos' “Palaia te kai nea Diathiki” (Kakoulidi-Panou 200o) or Morezinos' "Klini Solomontos" (Kakoulidi-Panou et al. 2007), as well as an anthology of demotic prose texts of 16 th century edited by Kakoulidi-Panou, Karantzola \& Tiktopoulou (in press).
\end{abstract}

\section{Keywords}

Early Modern Greek - subordination - complementation - Balkan languages

* Special thanks are due to Ioannis Fykias and Isabella Greisinger (both at the University of Salzburg) for their valuable remarks. We also cordially thank the two anonymous reviewers for their comments that contributed substantially to our improving this paper. 


\section{Introduction}

1.1 The Standard Modern Greek (sMG) Complementation System

Due to the drastic reduction of non-finite verbal forms in Modern Greek ${ }^{1}$ (MG) as a consequence of the gradual loss of the category 'infinitive'2 (cf. Joseph 1983: 37-84), the complementation system of the language makes use of a number of subordinating markers that introduce finite verbal types. Along general lines, verbs of saying, thinking, believing and other predicates that demand a clause in order to be semantically completed select complements introduced by the conjunctions 'ó $\tau$ ' óti and its slightly more colloquial counterpart ' $\pi \omega \varsigma$ ' pos (1). The conjunction ' $\pi 0 v$ ' $p u$ introduces complements after the so-called factive verbs $(2),{ }^{3}$ namely verbs that commit "the speaker to the truth of a subordinate proposition" (Matthews ${ }^{2} 2005:$ 125). Verbs expressing deontic and dynamic modality (obligation, necessity, willingness, ability, purpose), aspectual and causative verbs, as well as predicates expressing command or ordering select finite verbs headed by the proclitic mood particle $n a$ (3). The configuration $n a$ + verbal form is traditionally called the subjunctive $e^{4}$ and although the verb form after $n a$ is not morphologically marked for mood, there are good reasons to put forward that a na-clause is not merely a complement construction with modal semantic content but a genuine non-indicative mood.

1 There are basically two non-finite verbal formations in colloquial MG: A converb (in the sense of Haspelmath 1995, also often called a "gerund", cf. e.g. Holton et al. ${ }^{2} 2012$ : 306 f.) with the ending $-o(n)$ das / $-o(n)$ das that stems from the archaic present participle (cf. Manolessou 2005a) and an infinitive-like component of the analytic perfect tenses that is marked with

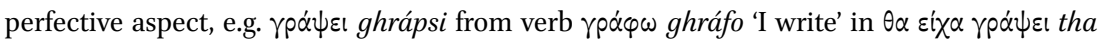
ikha ghrápsi "I would have written" (cf. Joseph 1983: 69f.).

2 The non-finite verbal form after various forms of the verb $\varepsilon \chi \omega$ ékho in the perfect tense is not taken here into consideration because it is not used as a complement of any predicate.

3 Cf. Roussou 2006: 9o ff.

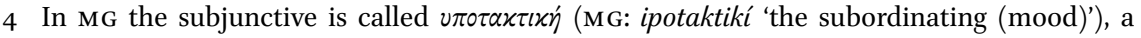
term going back to the Hellenistic grammatical tradition. The term is found in older MG grammars (for example in the Grammars of Manolis Triantaphyllidis [1941] ${ }^{8} 1998$ or Agapitos Tsopanakis (1998) as well as in modern descriptions of the language (cf. e.g. PhilippakiWarburton 1994; Philippaki-Warburton \& Spyropoulos 2004; Holton et al. 2012: 264f.; but different approaches in Hesse 2003: 12, and Mackridge 1985: 104). In favour of a mood analysis of the $n a$-construction, cf. Sampanis 2012. 


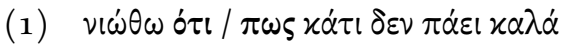

njótho ótipos káti dhen pái

feel.1SG.PRES.IND. THAT THAT ${ }_{2}$ something not go.3SG.PRES.IND

kalá

well

'I have the feeling that something is not going well'

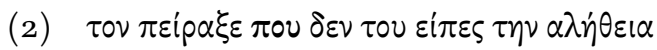

ton píraxe pu dhen tu ipes

him annoy.3SG.AOR.IND. THAT not he.GEN. tell.2SG.AOR.IND.

tin alíthya

the-truth.ACC.SG.F.

'It annoyed him that you didn't tell him the truth'

(3) $\pi \rho \circ \sigma \pi \alpha \theta \omega^{\prime} v \alpha \mu \alpha^{\prime} \theta \omega \alpha \rho \alpha \beta \iota \alpha \dot{\alpha}$

prospathó na mátho araviká

try.1SG.PRES.InD. M.PRT learn.1SG.(+perf.) Arabic.ACC.PL.N.

'I am trying to learn Arabic'

To complete the picture of complementation in MG, we might make reference to clauses introduced by $\mu \eta / \mu \eta \dot{\pi} \omega \varsigma$ mi / mípos 'lest' after verbs of fearing (Holton et al. ${ }^{2}$ 2012: $545 \mathrm{f}$.) as well as embedded indirect questions (ibid.: $540 \mathrm{ff}$.). Yet, these clauses oscillate between complementation and adverbial subordination ( $m i$ / mípos-clauses entail a causal or final flavor while indirect questions basically deliver adverbial information). Since these two categories are not crucial for our analysis herein, we will not further discuss them. ${ }^{5}$

\subsection{Pleonastic Complement Markers in Early Modern Greek (EMG)}

An important feature of the complement markers óti- pos, pu and $n a$ is that they cannot occur simultaneously within a single complement clause in MG. ${ }^{6}$ Certain predicates can select either one or another complement (or even all three) but in this case the semantics of the predicate varies in accordance with

5 Roussou (2006: $76 \mathrm{ff}$.) includes $\alpha \nu$ an 'whether, if', in cases of indirect "yes-no" questions to the MG complementisers. For an overview of the SMG complementation, cf. Roussou (ibid.) and Holton et al. ${ }^{2} 2012: 543 \mathrm{ff}$.

6 The indeclinable relative pronoun $p u$ which can co-occur with a $n a$-verb is not identical to the factive conjuction $p u$ discussed here. 
the modal content of the complement. ${ }^{7}$ Still, diachronic research can reveal that a parallel occurrence of these markers has been possible in the history of Greek. ${ }^{8}$ Consider the examples below (4-6) from the 16th c.:

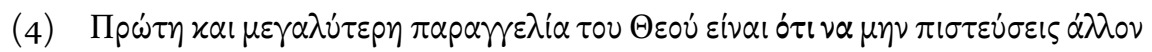

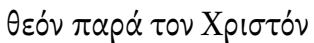

próti ke meghalíteriparangelía tu Theú íne óti na min first and greatest-order.NOM.F. the-God.gen. is THAT M.PRT. not pistefsis álon theón pará ton Christón believe.2sG.(+perf.) other-God.ACC.SG. than the-Christus.ACC.sG. 'The first and greatest order of God is that you should not believe in another God than Christus.' (Anthology: 24)

(5) $\quad 0 \lambda \pi i \zeta \omega \pi \omega \varsigma \nu \alpha \mu \varepsilon \varepsilon v \pi \lambda \alpha \gamma \chi \nu l \sigma \tau \varepsilon i$ xal $\varepsilon \mu \varepsilon \dot{v} \nu \alpha$ olpizo pos na me hope.1Sg.PRES.IND. THAT 2 M.PRT. Me.ACC.CL. efplachnistí ke eména have.mercy.3sG.(+perf.) and me.ACc. 'I hope that (she) will have mercy on me too.' (Morezinos: 259/243)

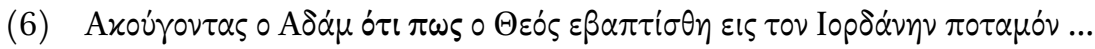
akúghondas o Adham óti pos otheós hearing the-Adam.NOM. THAT THAT 2 the-God.NOM. evaptísthi is ton Iordhánin potamón was-baptized.3SG.AOR.IND. in the-Jordan-river.ACC.M. 'As Adam heard that God was baptized in the Jordan river ....' (Kartanos, Testament: 289v)

All three examples are perfectly understandable for a MG native speaker. Yet, leaving aside slight semantic and morphological aberrations, the sentences deviate from SMG with regard to the fact that they select two complement markers in a way that is ungrammatical in SMG. In particular, in (4) ót i is ungrammatical in MG, similarly pos in (5) while the counterparts óti- pos can never appear together since they are in free distribution in MG.

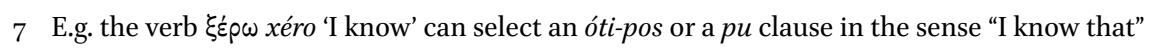
( $p u$ has then a strongly factive reading) or a subjunctive in order to show ability ("I know how ..., I am able to ..."). Cf. Roussou 2006: $57 \mathrm{f}$.

8 Cf. Kapsomenos (1968) on the accumulation of conjunctions from Post-Classical Greek onwards. Cf. Roussou 2009: 375 f. 
The instantiations of these syntactic structures in the corpus we researched (cf. next section) may initially seem to be "pleonastic" if not "arbitrary", however it is possible to find particular patterns of distribution, as we will see in this paper.

\subsection{Corpus}

The corpus we have examined for this research derives from literary and nonliterary texts of the 16th century. Generally speaking, the period from the late $15^{\text {th }} \mathrm{c}$. until the mid-17th c. is an extremely important one for the vernacular languages in Europe, as well as for the language sciences. Historians of language sciences, like Sylvain Auroux, have noticed (1994: 71 and passim) that the late $15^{\text {th }} \mathrm{c}$. was the beginning of the second techno-linguistic revolutionthe first one having been the invention of writing in the third millennium BC: this massive grammatisation ${ }^{9}$ process of vernacular languages of Europe (and of other continents as well), consisted of the production of dictionaries and grammars of all world languages on the basis of the Greco-Latin grammatical tradition. Actually, although most major European languages were attested in written form since the $9^{\text {th }} \mathrm{c}$. and the European Middle Ages was aware of dialectal and linguistic diversity, until the Renaissance a kind of complementarity seems to have existed between the "sacred" languages (Hebrew, Ancient Greek, Latin) — languages of literacy, power and religion — and the vernaculars.

From another point of view, this dynamic appearance of vernacular languages as written (and not only oral) languages, is considered the first ecolinguistic revolution in Western Europe, namely a transaction that is "... to substitute an ecology of communication dominated, in formal uses, by Latin, with an ecology based on the coexistence, in more or less territorialized spaces, of this universal medium and a common language." (Baggioni 1997: 74).

Regarding the Greek language, after a poorly documented period (7th-12th c.), ${ }^{10}$ there has been nothing comparable to the quantity and quality of prose writing process attested from the 12 th, a process that peaked in the late $15^{\text {th }} \mathrm{c}$., which reflect the vernacular Greek in different degrees. A variety of narrative texts (e.g., chronicles, lives of saints, homiletic texts, prophetic and apocalyptic visions, romance, parody and satire, etc.) and non-narrative ones (e.g., legal works, regulations, portolans, educational books, dictionaries, books of arithmetic, exorcisms, letters, etc.) are available in manuscript and/or printed form.

The term is in French and should not be confounded with the English terms 'grammaticisation'/ 'grammaticalization'.

$10 \quad$ Cf. Jeffreys 1996. 
250 extracts from all kinds of prose texts mentioned above-unpublished for

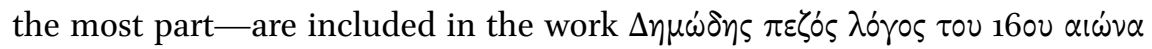
(Kakoulidi-Panou, Karantzola \& Tiktopoulou, in press, c. 500 pages). They stem from various regions of the Greek-speaking world (mainly Crete, Ionian Islands, Constantinople and mainland Greece), providing valuable information about the linguistic situation at that time, with respect to the dialectic and stylistic variety or the overall development of EMG. Because of its representativeness, this anthology will be our main body of reference for the study of the distribution of "pleonastic" use of complement markers in EMG.

In addition, our corpus comprises two more extensive texts:

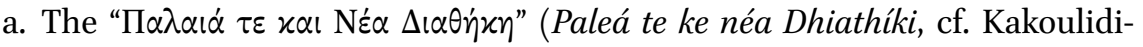
Panou (ed.): 2000) of the Corfiot Ioannikios Kartanos (Venice 1536, c. 145,000 words), the first translation in vernacular Greek of excerpts of the Bible;

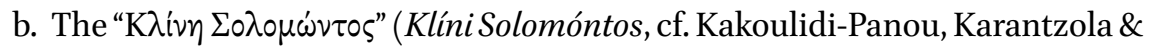
Chalvatzidaki, (eds.). 2007) of the Cretan Ioannis Morezinos (1598, c. 82,000 words), which records sixty miracles of the Virgin Mary, in Cretan dialect (ms Xiropotmou, 1602).

The occurrences of "pleonastic" marker constructions are numerous within the corpus and therefore the phenomenon cannot be regarded as sporadic or a sort of erroneous stylistics. Moreover, in terms of statistics, the occurrences of the three combinations vary in frequency and with regard to the author. Thus, the ót $i+n a$ appears the most within the Anthology (59×) in comparison to the ót $i+$ pos $(12 \times)$ and the pos $+n a(4 \times$, the less frequent constellation within this compilation of texts, cf. Figure 1). One may observe in turn that $o ́ t i+n a$ is preponderant in absolute numbers in Kartanos' book (more than $283 \times{ }^{11}$ vs. 4 instances of pos $+n a$ complements ${ }^{12}$ ) whereas it is not attested in

11 The number here, and in all other cases, refers to the occurrences in which the markers are aligned next to each other, so that no other lexical element is interpolated. There are instances of "pleonastic" usages of óti $+n a$ in which the two elements are separated, cf. ex. 16. These cases are most interesting for providing a structural analysis but are not easily traceable in statistic terms; therefore they are excluded from the numbers provided here.

12 There are several constellations of an accentuated pos 'how' (from which the nonaccented complementiser pos 'that' derives) with the particle $n a$. This case is irrelevant to our investigation herein and the only (simple) challenge is to discern between the interrogative and the complementing pos. It is reasonable to assume that the latter has a syntactic status parallel to óti. 


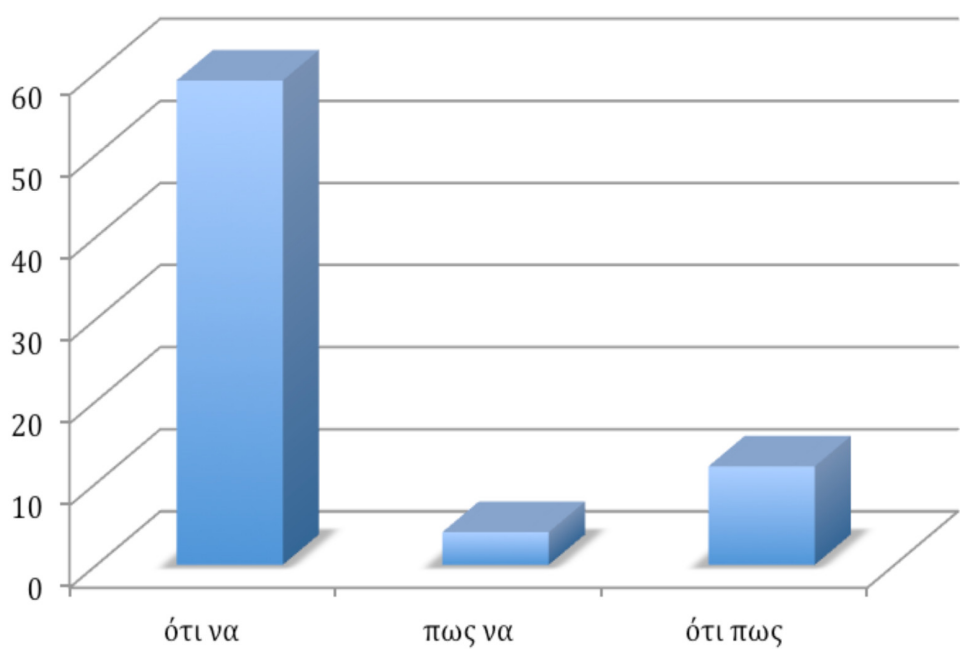

FIGURE 1 Distribution in EMG on the basis of "Anthology's" texts: óti + na: $59 \times$; pos + na: $4 \times$; óti + pos: $12 \times$.

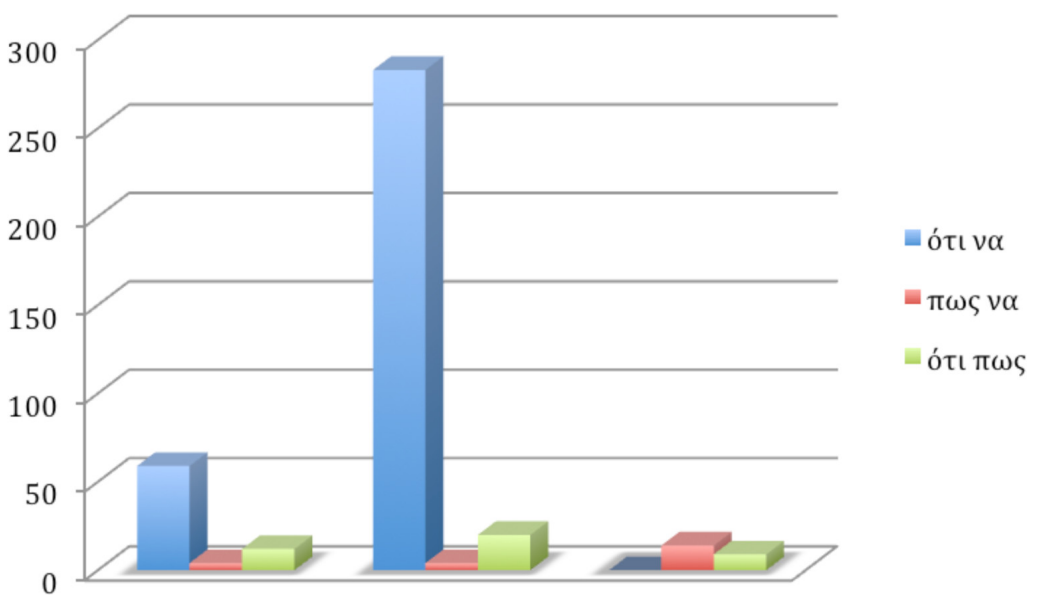

FIGURE 2 Distribution in EMG on the basis of the overall corpus: Anthology (see Figure 1), Kartanos (óti + na: 283×; pos + na: $4 \times$; óti + pos: $20 \times$ ), Morezinos (óti + na: o×;pos + na: $14 \times ;$ óti + pos: $9 \times)$ respectively.

Morezinos, who mostly employs the pos $+n a$ pleonastic structure (still only $14 \times$, cf. Figure 2). As we will also discuss later in this article, the discrepancy in distribution may be suggestive of a dialectically conditioned usage of the combined markers. 
As mentioned above, the distribution of the numerous attestations of the "pleonastic" complement markers may appear at first sight to be unsystematic and arbitrary, and indeed the sample we extract shows a variety of environments in which the combined markers emerge. Still, a closer examination of the subordinating usages of these structures allows us to trace regularities in their occurrence. In the case of complement clauses, we focused on the categories of predicates that select combined markers and their syntactic properties, so that we can reach an explanation of their function within the synchronic system of EMG. It should be borne in mind, however, that every text or author at that time differs from each other insofar as the syntactic system is concerned. This means that texts of different authors and from different regions may have developed distinct and not identical syntactic systems despite their belonging to the same linguistic continuum. Hence, in the absence of a well-established vernacular MG norm, the image of the Greek language at that time as a whole creates the impression of being in a state of flux or, as Hopper (1987) would put it, "emergent".13 Yet, it is not our intention herein to express a functional stance against a formal one (cf. discussion in Fischer 2007: 53 ff.), but rather to provide an overall account of the parallel phenomena in examination which can be possibly described, for example, by the notion of grammars in completion put forward in Kroch 1989. Besides, as long as we are seeking patterns in the usage of the "pleonastic" conjunctions, a functional analysis is plausible, especially within the work of a particular author or a certain genre, etc.

Having this theoretical background in mind, in this chapter we will examine the distribution of all three cases of "pleonastic" introductory markers, beginning with the ót $i+n a$ clauses which constitute the majority of the cases we researched.

13 Cf. Hopper (1987: 148): "Because grammar is always emergent but never present, it could be said that it never exists as such, but is always coming into being. There is, in other words, no 'grammar' but only 'grammaticization'-movements toward structures which are often characterizable in typical ways. It goes without saying that many phenomena which we would agree to call grammatical are relatively stable and uniform. That is not in dispute. The point again is that any decision to limit the domain of grammar to just those phenomena which are relatively fixed and stable seems arbitrary." 


\section{1 óti Plus na}

The óti + na clauses serve as means of both adverbial and complementary subordination, although the former usage is far less frequent than the latter; ${ }^{14}$ therefore our focus lies on the complementary function of this structure.

2.1.1 ót $+n a$ Introducing Adverbial Clauses

The adverbial clauses introduced by óti + na could have a final (7) or resultative $^{15}(8)$ content. In these functions the óti + na final clauses competed the $\delta i \alpha$ $+v \alpha$ dhiá $+n a$ 'in order that' ones (dhiá literally means 'for'), whereas óti + na resultative appeared along with the resultative clauses that were introduced by a "plain" óti (cf. Karantzola 2000: 548$)$.

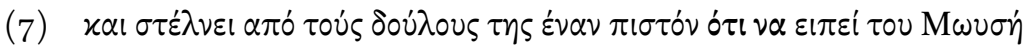
ke stélni apó tus dhúlus tis and sends.PRES.IND. from the-servants.ACC.PL.M. she.GEN. énan pistó óti na ipí tuMoisí one-trusty.ACc.M. THAT M.PRT say.3sg.(+perf.) the-Moses.gen. '... and out of her servants [she] sends a trusty one so that he says to Moses ...' (Kartanos, Testament 155v)

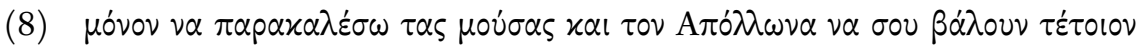

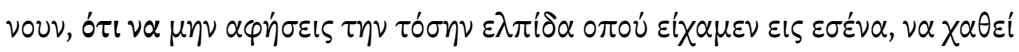
mónon na parakaléso tasmúsas ke ton Apólona only M. PRT plead.1SG.(+perf.) the-Muses.Acc. and the-Apollo.Acc. na su válun tétjonnun óti na M.PRT you.gen. put.3PL.(+perf.) such mind.ACC.SG.M. THAT M.PRT min afísis tin tósin elpídha opú not abandon.2Sg.(+perf.) the-such-hope.Acc.sG.F. which ikhamen is eséna nakhathí have.3PL.PRET.IND. to-you.Acc. M.PRT get.lost.3Sg.(+perf.) 'I only want to plead the Muses and Apollo to give you this sort of sense, so that you don't let all the hope we had for you perish' (Anthology: 93)

\footnotetext{
14 In the anthology only 11 out of 6o óti-na clauses arguably have an adverbial interpretation. In turn, in Kartanos 39 instances out of 283 óti-na clauses could be designated as adverbial.

$1517 \times$ out of 39 adverbial óti-na clauses have a resultative reading.
} 


\subsection{2 óti + na Introducing Complementary Clauses}

Despite their adverbial realizations, the ót $i$ + na clauses chiefly served as means of complementation. It is in fact mainly in this use that we can observe the syntactic function of the construction. The arguably ${ }^{16}$ earlier attestations of the óti + na complement clauses from Digenis Akritas (ex. (9), circa 12th c.) and the Chronicle of Morea (ex. (10), probably circa 14th c.), both texts transmitted via manuscripts from $15^{\text {th }} \mathrm{c}$. onwards, suggest a joint use of both markers at least during the Late Medieval period:

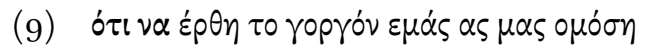

óti na érthi toghorghón emás as mas

THAT M.PRT. come.3sG.PERF. the-fast us let.PRT us omósi

swear.3sG.(+perf.)

'Let him swear to us that he will come back quickly' (Digenis Akritas, Esc.: $412)^{17}$

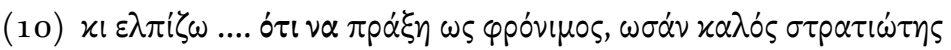

ki elpizo óti na práksi os

and hope.1SG.PRES.IND. THAT M.PRT. act.3sG.(+perf.) like

frónimos osán kalós stratiótis

prudent.NOM.sG.M. like good-soldier.NOM.SG.M.

'... and I hope that he will act like a prudent and good soldier' (Chronicle of Morea: 4012)

The meaning of $n a$ in these Medieval Greek examples oscillates between futurity and modality. ${ }^{18}$ In SMG, the two predicates meaning 'to swear' and 'to hope' may select either a subjunctive complement clause or a declarative óti/pos + future tense ${ }^{19}$ (for example MG: elpizo na érthi vs. óti tha érthi (roughly and literally: "I hope (for) him to come" vs. "I hope that he will come").

16 Cf. Horrocks ${ }^{2} 2010$ : 333 f. and 349 f. Bear in mind that a secure chronology for the composition of both epic poems is still disputable.

17 In Jeffreys 1998: $268 \mathrm{f}$.

18 On modality, cf. Roussou 2006: 38 , fn. 12. On the connection between futurity and modality, cf. Lyons (1977: 816): "reference to the future, unlike reference to the past, is as much a matter of modality as it is of purely temporal reference".

19 The future tense in MG is formed by the futurity particle $\theta \alpha$ tha + a verbal form marked for aspect. Its distribution is identical to the mood particle $n a$. The two particles cannot 
It may have been in this sort of usages that the ót + na configuration arose: Initially only óti played the role of subordinator and $n a$ could express the future tense, possibly somehow tinged with a sense of modality ${ }^{20}$ (it is anyway a common feature of futurity and modality that encode an "irrealis" reading as opposed to the "realis" one of the present or past indicative, cf. Palmer $2_{2}^{2}$ 2006: 104ff.). In EMG similar constructions are attested, though they are fairly uncommon (in Kartanos in no more than 10 ex. and in the Anthology, only once could $n a$ be interpreted as principally a future marker):

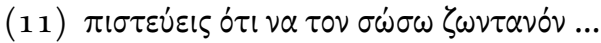

pistévis óti na ton sóso

believe.2SG.PRES.IND. THAT M.PRT. him catch-up.1SG.(+perf.) zondanón

alive.ACC.SG.M.

'Do you believe I will make it to see him alive?' (Kartanos, Testament 279v)

Along with these cases, in our EMG corpus the ót $i+n a$ complement clauses are selected by the following sets of predicates:

\subsubsection{Commissives}

In EMG commissive ${ }^{21}$ predicates, such as $\alpha \pi \circ \varphi \alpha \sigma i \zeta \omega$ apofasizo 'decide', $\tau \dot{\alpha} \sigma \sigma \omega$

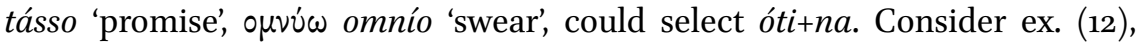
written by Sofianos, author of a grammar of vernacular Greek of the 16th c. (cf. Legrand 1870):

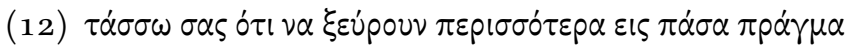

táso sas óti na ksévrun

promise.1SG.PRES.IND. you.GEN. THAT M.PRT. know.3PL.

perisótera is pásaprághma

more.ACC.PL.N. in every-thing.ACC.SG.N.

'I promise that they will have more knowledge in every domain' (Anthology: 9 )

co-occur, while tha does appear after an óti-pos or a pu complementiser (contrary to $n a$ ). In Late Medieval and Early Modern Greek tha is not yet attested (cf. Markopoulos 2009).

20 On the semantic and syntactic distinctions of $n a$ in Medieval and Modern Greek, cf. Markopoulos 2007 .

21 Cf. Austin ( $\left.{ }^{2} 1975: 157\right)$ : verbs that "commit the speaker to a certain course of action". 
After commissives, the $n a$ headed by óti has a strong futurity reading; thus these complement clauses relate to the cases we saw in the previous section. In Kartanos, there are only 12 instances of this sort, in the Anthology, $5^{\times}$.

\subsubsection{Directives}

The ót $i+n a$ complements appear after verba dicendi, especially after the verb $\lambda \dot{\varepsilon} \gamma \omega \omega$ légho 'say, tell'. The verbs of saying that select an óti + na clause may maintain their prototypical meaning of uttering/ speaking (13), although in most cases $^{22}$ they obtained a "directive" ${ }^{23}$ reading of the sort "I tell somebody to do something" (14):

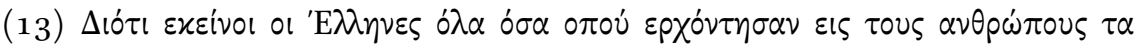

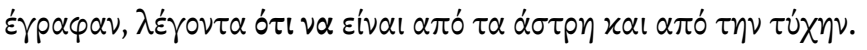
dhióti ekíni iélines
óla ósa
opú

because those-the-Greeks.NOM. all-these.NOM.N. that.REL.PR.

erkhóndisan is tus anthrópus ta éghrafan

come.3PL.PRET. to the-humans.ACC.M. these write.3PL.PRET.

léghonda óti na íne apó taástri ke apó

saying.GER. THAT M.PRT. are.3Pl. from the stars.ACC.N. and from

tin tíchin

the-fate.ACc.F.

'... Because the Greeks of that time recorded everything occurring to people, saying that they are caused by the stars and fate.' (Anthology: 6o)

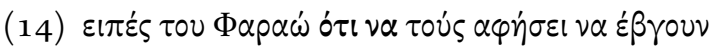

ipés tuFaraó óti na tus afisi

tell.2SG.IMP. the-Pharaoh.GEN. THAT M.PRT them let.3SG.(+perf.)

na évghun

M.PRT go-out.3PL.(+perf.)

'Tell Pharaoh to let them leave!' (Kartanos, Testament 157v)

In accordance with the directive reading of verba dicendi, predicates of order, request and the like (mainly the verbs opí $\zeta \omega$ orizo 'ordain, order', $\pi \alpha p a \gamma \varepsilon \dot{\varepsilon} \lambda \omega$ parangélo 'order, charge sb to', $\pi \alpha \rho \alpha \varkappa \alpha \lambda \omega$ parakaló 'beg, plead') also select ót $i+$ na clauses. (15-16):

\footnotetext{
22 There are only 3 cases in Kartanos in which légho has a genuine verbal reading. All other instances $\left(5^{2} \times\right)$ are explicitly directives.

23 "Directive: Speech act by which speakers direct or elicit action by others. Thus an order; also e.g. a question, since it invites an answer." (in Matthews ${ }^{2}$ 2005: 99).
} 


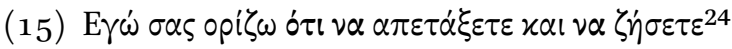

eghó sas orízo óti na apetáxete

I you.gen.PL. order.1SG.PRES.IND. THAT M.PRT fly.2PL.(+perf.)

ke na zisete

and M.PRT live.2PL.(+perf.)

'I order you to fly and live' (Kartanos, Testament 247)

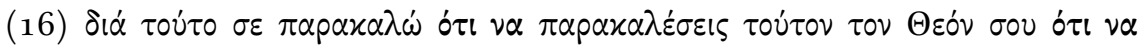

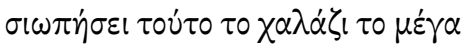

dhia túto se parakaló óti na parakalésis

for that you.ACC. beg.1SG.PRES.IND. THAT M.PRT beg.2SG.(+perf.)

túton ton Theón su óti na siopísi

this-the-god.ACC. your THAT M.PRT make.stop.3SG.(+perf.)

túto to khalázi to mégha

this-the-hail-the-great.ACC.SG.N.

'Therefore I beg you to beg this God of yours to make this great hail cease.' (Kartanos, Testament 161v)

In terms of statistics, the directive verbs form the largest predicate category selecting an óti + na clause. In Kartanos, no less than 140 out of 283 óti + na complements are selected by directives (and $22 \times$ out of 59 in the Anthology), so that it is straightforward that at least in Kartanos the directives constitute the syntactic context par excellence in which the ót $+n a$ constellation is traced.

In the first place, the compatibility of óti with $n a$ is explainable by postulating that óti in EMG did not necessarily introduce assertive clauses exclusively, as is the case in MG, but it has a broader character, being a generic complementiser ${ }^{25}$ compatible with the irrealis reading of a $n a$-verbal form, i.e. a MG subjunctive, analogous to the French que or the Italian che (both can select either the indicative or the subjunctive). ${ }^{26}$ Still, this could not be "the whole story"; otherwise, óti would head any na-verbal form. Therefore, in

24 In coordination, the particle $n a$ is obligatorily repeated while óti normally appears only once. Moreover, $n a$ always forms a cluster with the verbal form (only the negator $\mu \eta \nu \mathrm{min}$ and unstressed clitic object pronouns may intervene between the mood particle and the verbal form, as in $\mathrm{MG}$ ). It seems reasonable to suggest that ót $i$ is a conjunction/complementiser while $n a$ is part of the verbal paradigm.

25 Cf. also Roussou 2009: 382.

26 Whether there has been an influence of Italian dialects (e.g. Venetian) on Western Greek dialects could be an interesting working hypothesis! 
this constellation óti seems to frequently encode "directivity" by introducing an embedded complement that expresses a non-assertive/ performative utterance. $^{27}$

A related line of argumentation is to associate the selection of $o t i+n a$ with indirect and reported speech, in the sense that ót introduces an embedded $n a$-subjunctive. In a non-embedded context, the $n a$-subjunctive can express wishes, desires, requests, orders, and less forceful commands than the imperative (Holton et al. ${ }^{2} 2012: 264$ ). Additionally, an embedded subjunctive could encode a reported imperative. We will return to ót $i$ as a marker of indirect/ reported speech in 2.3 .

\subsubsection{Causative Verbs}

Causative verbs resemble the directives both semantically and syntactically: On the one hand the causative verbs exhibit a sort of intentionality similar to the one of directives; on the other hand, the argument structure has the form "I cause somebody to do/become something":

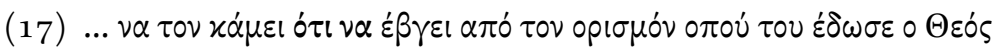 na ton kámi óti na évghi
M.PRT him make.3sg.(+perf.) THAT M.PRT come-out.3sG. (+perf.)
apó tonorismón opú tu édhose

from the-order.ACC.M. which to-him.GEN. gave.3SG.AOR.IND.

o Theós

the-God.NOM.M.

'... [he intended] to make him disobey the order that the God gave to him' (Kartanos, Testament 72v)

There are 15 ót $+n a$ complements after causatives in Kartanos. In the anthology, this usage is not attested.

\subsubsection{Impersonal Modal Verbs}

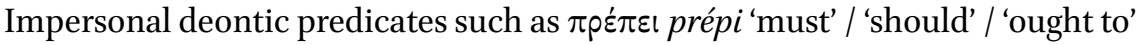

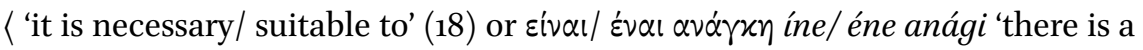
need (for sb) to' (19) select ót $i$ + na clauses:

27 Roughly in the sense of Austin 1962 but in a more grammatical sense. For example, reported speech after directives usually corresponds to an imperative in direct speech: "I tell / order (etc.) you/sb to do sth" > "Do sth!". 


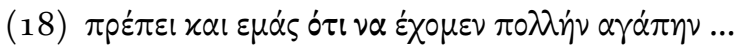
prépi ke emás óti na ékhomen is-necessary.IMPRS. and Us.ACC. THAT M.PRT have.1PL. polín aghápin much-love.ACC.SG.F.

'We should have much love ....' (Anthology: 49)

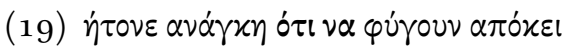

ítone anági óti na fíghun apóki was need.NOM.sG.F. THAT M.PRT leave.3PL. (+perf.) thence 'There was a need for them to leave away from there.' (Kartanos, Testament 236)

In an analogous way to directives and causatives, predicates expressing deontic modality convey "intentionality" meanings from the side of the speaker if the proposition is addressed to another person (quasi "it is necessary for you to do sth" $\rangle$ "I want/tell you to do sth"); therefore they express directivity. Given the nature of the texts (admonitions, (divine) orders, incitements and the like), it is reasonable to postulate that deontic modality constitutes an indirect means of expressing the will of the speaker.

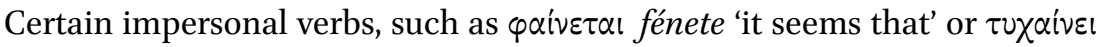
tikhéni 'it is the case that', can select ót $i$ na complements as well, somehow following the impersonal deontic predicates. In total, there are 19 such cases in Kartanos, 10 in the Anthology.

\subsubsection{Volitionals}

Volitional predicates, especially the verb $(\varepsilon) \theta \dot{\varepsilon} \lambda \omega(e)$ thélo 'I want' could select an óti + na clause:

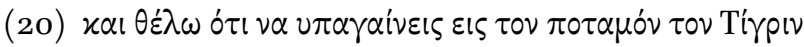

ke thélo óti na ipighénis is

and want.1SG.PRES.IND. THAT M.PRT go.2SG.(-perf.) to

ton potamón ton Tíghrin

the-river.ACc.M. the-Tigris.ACc.M.

'... and I want you to go to the Tigris River.' (Kartanos, Testament 77)

In several cases the volitional predicates seem to be followed by ót $i+n a$ when directivity is involved, i.e. when a speaker addresses his will to another person ("I want you to do sth"), while in cases of subject co-reference ("I want to do sth") a bare subjunctive clause (a "plain" na-verbal form) is preferred (22): 


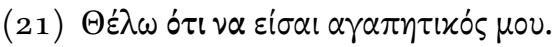

thélo óti $\mathbf{n a}$ ise aghapitikós mu want.1SG.PRES.IND. THAT M.PRT be.2SG. lover.NOM.M. my.GEN. 'I want you to be my lover.' (Kartanos, Testament 147v)

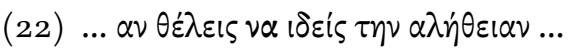

an thélis na idhis tinalithyan

if want.2SG.PRES.IND. M.PRT see.2SG.(+perf.) the-truth.ACC.F.

'... if you want to see the truth ...' (Kartanos, Testament 245v)

Nevertheless, there are many counterexamples that may question this interpretation. For instance, in (23) ót $i+n a$ does not seem to implicate directivity (or it does in a very indirect manner), while in (24) disjoint subject reference (and thus implicitly directivity) is possible with the bare $n a$-subjunctive: ${ }^{28}$

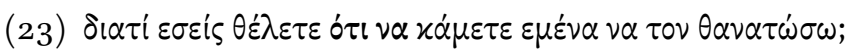

dhiatí esís thélete óti na kámete

why you.NOM.PL. want.2PL.PRES.IND. THAT M.PRT make.2PL.

eména na ton thanatóso

me M.PRT him kill.1SG.(+perf.)

'Why do you want to make me kill him?' (Kartanos, Testament 271v)

(24) $\mathrm{H} \mu \varepsilon i \varsigma$ $\theta \dot{\varepsilon} \lambda \circ \mu \varepsilon \nu \nu \alpha \sigma \tau \alpha \nu \rho \omega \theta \varepsilon \dot{~}$

imis thélomen na stavrothí

we want.1PL.PRES.IND. M.PRT get.crucified.3SG.(+perf.)

'We want him to be crucified.' (Kartanos, Testament 272)

Generally, in certain cases (and not only after volitionals) it is possible to observe a parallel occurrence of óti $+n a$ and bare $n a$-subjunctive after the same or similar predicates within the same context. In the following text,

28 However, compare the following ex. of directive usage of thélo within the same paragraph in Kartanos' text:

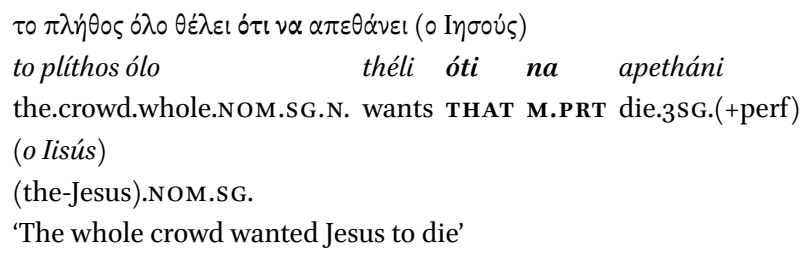


a vernacular rendition of the Ten Commandments, the (directive) predicate

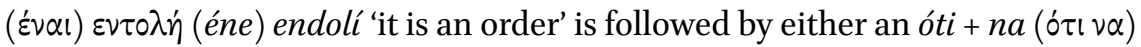
or a $n a(v \alpha)$ clause:

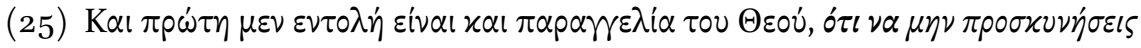

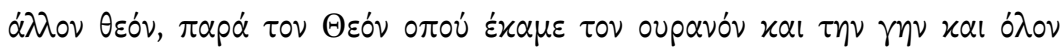

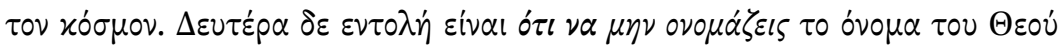

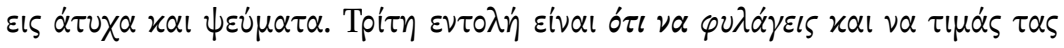

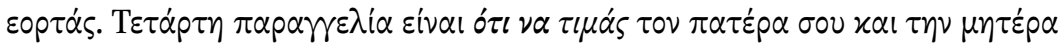

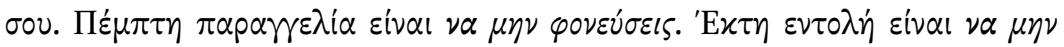

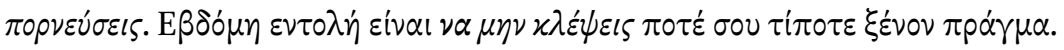

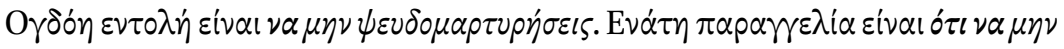

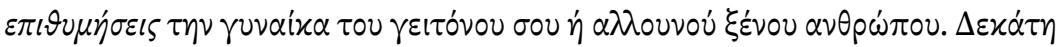

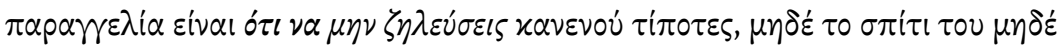

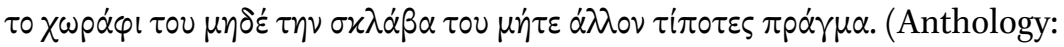
24)

In sum, volitionals appear 33 times in Kartanos, so the employment of óti $+n a$ after this category does not seem to be prototypical in this text. 18 out of the 33 complements have disjoint subject reference between the matrix and the embedded clause, therefore one may assume that they have a similar function as directives (from a pragmatics point of view, when I tell an addressee that I want them to do sth, I implicate that they had better do it!). However, the rest of the cases do not exhibit disjoint reference, so they could not be categorized as sensu stricto directives, unless we suppose that directivity towards an addressee is associated with intentionality in general in the case of volitional predicates (thus, expression of will is directed either to an addressee or to the subject of the will as well). We return at this point in the next section.

\subsection{3 óti Plus na and Obviation Effect?}

If we postulate that directivity is in play when we deal with ót $i$ + na complementation in Kartanos, who provides us the most cases of this structure (in our view statistically this is a justifiable assumption), a syntactic corollary is that necessarily ót $i n a$ clauses entail disjoint reference between the subject of the matrix and the embedded clause. A tentative "working hypothesis" is to examine if ót $i$ contributes both to the directive reading of the overall construction as well as to subject obviation.

Consider the following phenomena in two languages of the "Balkansprachbund" (i.e. the languages of the Balkan that share a number of similar-lexical, morphological and syntactic — features, cf. Tomić 2004 and 2006), namely in 
Romanian and in Albanian. Both languages make use of a sort of complementiser that introduces the complement subjunctive clause. ${ }^{29}$ In Romanian, the lexical element $c a$ appears along with the subjunctive, which is marked by the mood particle $s a ̆$. The "subjunctive complementiser" $c a$ has a variety of functions ${ }^{30}$ on the left periphery of the embedded clause such as topic, focus or plainly introducing a subjunctive complement after certain sets of predicates (26). In Albanian, the "relativum generale"31 që can also introduce subjunctive complements after several verbal categories, as in (27).

(26) Romanian:

Am vrut ca Mihai să plece

have.1SG.IND.PRES. wanted.PRC. COMPL Mihai M.PRT leave.3Sg.

mîine

tomorrow

'I wanted for Mihai to leave tomorrow.' (In Alboiu 2004: 63)

(27) Albanian:

Jani do që fëmïët të

John want.3SG.PRES.IND. COMPL children-the.NOM.FEM. M.PRT

punojnë

work.3SG.

'John wants the children to work.' (In Terzi 1992: 17)

There are some interesting facts to be considered concerning the examples above: in both Balkan languages the "subjunctive complementisers" are widely used in the case of disjoint subject reference, like in cases the examples manifest. In Romanian the occurrence of $c a$ obligatorily triggers obviation (cf. Terzi 1992: 105f. and Tomić 2006: 517), while in Albanian the picture is more complicated, since $q \ddot{e}$ introduces subjunctive complements even in cases of subject co-reference (cf. Tomić 2006: $589 \mathrm{ff}$.). ${ }^{32}$ Nevertheless, both languages have

29 Bear in mind that the subjunctive in the Balkansprachbund languages resembles the Greek subjunctive by comprising a mood particle that is adjacent to a verbal form (Joseph 1983 remains a major work on the topic). In our view the mood particle is neither in Greek nor in the Balkansprachbund languages that we examine here a complementiser.

30 Cf. Dobrovie-Sorin 1994: $94 \mathrm{ff}$. and Alboiu 2004: $57 \mathrm{f}$. for details.

31 Cf. Tomić (2006: 585, fn. 304): "Qё is actually the Albanian relativum generale (general relativizer/complementizer) on a par with the Macedonian što and the Modern Greek pu."

32 It is beyond the scope of this paper to go into great details about the phenomena in 
in common that $c a$ and $q \ddot{e}$ cannot occur after certain control verbs. According to Tomić (2006: 518 for Romanian; ibid.: 588 for Albanian), the Romanian $c a$ has stricter distribution than the Albanian që, since the former is excluded in control environments, while the latter is blocked only after the verbs mund "can/may/possible" and duhet "must/should/need/ought/ be necessary".

What does the Balkan case suggest for EM G? Although it is obvious that every language has developed a different frame of usage concerning the "subjunctive complementisers", there are certain similarities. The complementiser plus subjunctive complement construction is favoured in obviation constructions and is basically excluded after particular control predicates.

If this is the case, how can we account for the counterexamples after volitional verbs like the ones we saw in (23-24)? First of all, volitional predicates are not obligatorily control verbs or obviation verbs. ${ }^{33}$ Since the subjects of their complement verbs can exhibit both joint or disjoint reference to the matrix subject they differ both from the intentional and causative verbs we examined before, while they somehow resemble verbs such as the commissive omnio 'I swear' or elpizo 'I hope' (cf. ex. 11 and 12 from Late Byzantine Greek. In our EMG corpus omnio may select ót $i+n a$ clauses whereas elpízo plus ót $i+n a$ is extremely $\left.\operatorname{rare}^{34}\right)$. On the other hand, volitional and intentional verbs share the semantic property of expressing the willingness of the subject. Willingness and ability are parts of the so-called dynamic modality (cf. Palmer ${ }^{2}$ 2006: 70 and $76 \mathrm{ff}$ ), and while ability forms control structures, willingness can be either directed towards the subject of the verb or another person, and the latter case is then manifested by obviation. Intentional and causative verbs necessarily have complements with disjoint reference. Volitional verbs in turn can select either co-referent or non co-referent complement subject, as already said, so in a syntactic system in which the "complementiser slot" is open for the subjunctive

Romanian and Albanian we discuss here. A more systematic comparison between EMG and these languages from our side will be the topic of future research.

33 One should consider control and obviation as belonging to a continuum, in which absolute control lies on the leftmost edge while non obligatory control on the rightmost one. Deontic modal verbs or verbs expressing competence are placed on the left extreme, volitional verbs that do not demand control, on the right. In-between there are verbs of more or less partial control like the ones meaning "to try" and the like. Cf. Landau 2004 and for Greek, Roussou 2006: 123 .

There is only one attestation in the Anthology: 146. In Kartanos the verb elpizo is altogether rare. 
complements, the volitional verbs tend to "imitate" the directive ones. If this is the case, ót $i$ before $n a$ mainly marks disjoint reference and is preferred in directive/ obviation sentences, but given that the valency of the volitional verbs may allow the appearance of a complementiser, this may "pop up" also in cases of co-reference. It should be borne in mind though that the system of EMG is in flux and varies with regard to the region or the author, and even within a single text, consistency cannot always be found.

If this approach is right, we would expect that also in EMG there must be some restriction in the distribution of the ót $i+n a$ clauses as is the case in Albanian. Indeed, this construction rarely occurs after the control modal verb $\mu \pi \circ \rho \omega$ ' $(m)$ boró 'I can, I am able to'. Still, even in this case we can trace counterexamples within the whole corpus:

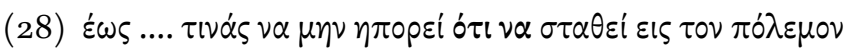

éos tinás na min iporí óti na stathí is

until someone M.PRT not can.3SG. THAT M.PRT stand.3SG. in

ton pólemon

the-war.Acc.

'... until (nobody) could stand in the war.' (Anthology: 134)

Nevertheless, these counterexamples are scarce, the case in (28) after the control verb $(m)$ boró is unique in the Anthology. Similarly, in Kartanos there is only a single case of this control verb selecting an óti + na clauses while in about 160 instances, $(m)$ boró selects a "bare" $n a$-subjunctive. Interestingly, there are no instances of ót $i+n a$ complements after the aspectual control verb $\alpha p \chi i \zeta \omega$ arkhizo 'I begin to'. Thus, in EMG, óti was not only a generic complementiser, which is not necessarily bound with assertive complementation, but in its function as an introductory marker of a complement could give rise semantically to directivity and, consequently, syntactically to obviation (although we should underline the fact that in this case syntax is the impact of a semantic function and not vice versa). Further research on this topic is required.

\section{2 pos Plus na}

In our corpus, the distribution of pos + na differs with regard to each author or text. As afore-mentioned, in SMG pos is a slightly more colloquial alternative to óti. In Kartanos, pos + na clauses appear in the same contexts as the ót $i+$ $n a$ constructions do (cf. ex. (5) in 1.2.), although the occurrences of pos + na are far less frequent within Kartanos' work. Similarly, in the Anthology, óti $+n a$ outnumbers pos $+n a($ cf. Figure 2). 
In a single case in the whole corpus, ót introduces a pos + na complement (29). This usage of óti, rare as it may be, is once again suggestive of the function of óti as an indirect/reported speech marker.

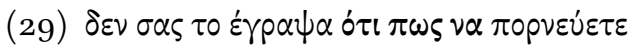

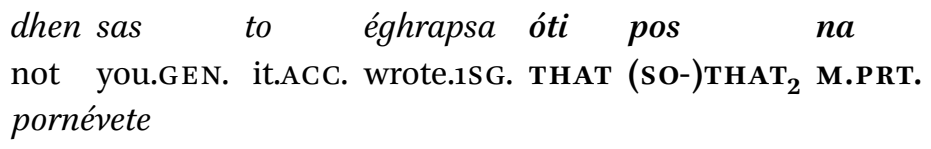

In Morezinos, on the contrary, there are no instantiations of ót $i+n a$ clauses, while pos $+n a$ is the most preponderant "pleonastic" constellation. The reason why ót $i+n a$ is not attested is the overall absence of ót $i$ in the work of the Cretan author. This fact could be an indication of a dialectal distinction between the Corfiot and the Cretan texts, namely that pos have replaced ót $i$ in the Cretan dialect, while it was already competitive to ót in Western dialects. ${ }^{35}$ Further research on this issue is a desideratum for us and will be presented in the future.

The "pleonastic" pos + na construction is not only numerically less common than the ot $i+n a$ clauses within the rest of the 16th c. corpus, but it is also selected by a more restricted set of predicates, namely by verbs expressing thought or judgement/ belief (verba putandi, cf. 30) or verbs like elpizo 'I hope'. This employment of pos $+n a$ is illustrated in (31) where both predicate categories are found in the same period:

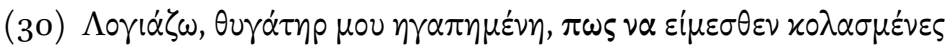
loyázo, thighátir mou ighapiméni, pos consider.1SG.PRES.IND. daughter.vOC. my dear.SG.VOC.F. THAT $\mathbf{T}_{2}$ na ímesthen kolasménes

M.PRT are.1PL. sinful.PL.NOM.F.

'My dear daughter, I consider us to be sinful.' (Morezinos, Klini Solom. $5^{26 / 505)}$

35 Cf. Nicholas 1996: 19. 


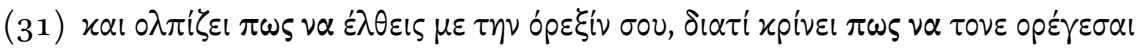

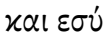

ke olpizi pos na élthis me and hope.3SG.PRES.IND. THAT 2 M.PRT come.2SG.(+perf.) with tinóreksín su dhiatí kríni pos na the-will.Acc.sG.F. your because believe.3SG.PRES.IND. THAT 2 M.PRT tone oréghese ke esí him desire.2sG.(-perf.) and you.NoM.

'.... and he hopes you will come on your own will because he believes that you will also desire him.' (Morezinos, Klini Solom. 286/260 v

The semantic link between these two predicate categories is that they are both future-oriented. The usage after elpizo is a continuation of the older "pleonastic" usage of a conjunction along with the mood particle $n a$ (cf. ex. (12)). In 2.1.2. we remarked that verbs like elpizo can select either a $n a$-subjunctive or a conjunction + future tense clause (elpizo na érthi vs. óti/pos tha érthi). A similar case is the SMG verb $\pi$ $\sigma \tau \varepsilon^{\prime} \omega$ pistévo 'believe', which semantically corresponds to the verb kríno found in (31) and can take a $n a$ - or an óti/pos + tha complement $^{36}$ (dhen pistévo na érthi ávrio vs. óti/pos tha érthi ávrio 'I do not believe that (s)he will come tomorrow').

Yet, given the paucity of attestations of pos $+n a$, as well as its distribution, it is obvious that this structure did not develop an association with directivity in Morezinos.

\section{3 óti Plus pos}

From a MG native speaker's point of view, the juxtaposition of the complementisers ót $i+$ pos is intuitively the "least acceptable"37 among the three construc-

36 Verbs of opinion, such as pistévo, usually select $n a$-complement if negated or in questions, cf. Roussou 2006: $68 \mathrm{f}$.

37 Jannaris (1897: § 1755) writes that the combination of the concurrent "declarative particles" are "of no rare occurrence" in popular speech and reports the following sentence:

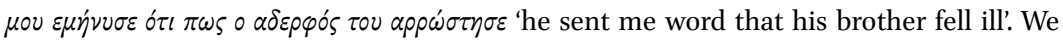
remain rather dubious about this claim, firstly because as we said in SMG this construction is not acceptable, secondly because Jannaris does not seem to make a distinction between the complementiser $\pi \omega \varsigma$ and the interrogative $\pi \omega$ s (in his analysis in polytonic Greek he shifts from interrogative $\pi \hat{\omega} \varsigma$ to complementiser $\pi \hat{\omega} \varsigma$ without mentioning any differentiation). Nevertheless, further research in dialectic texts may yield more such cases. 
tions we examine in this paper. ${ }^{38}$ This is reasonable if we take into consideration that óti and pos are supposed to occupy the same syntactic slot within a structure not only in MG, in which they are in free distribution, but also in EMG, for example in Kartanos, since they both occur conjoined with a $n a$-verbal form.

The ót $i+$ pos clauses are mostly selected by verbs such as léo 'say' (32) or ghráfo 'write' (33), narratives i.e. predicates that "report" sayings or events (34), perception verbs (35) and verbs of knowledge (36)

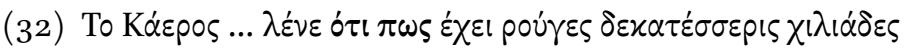
ToKáeros léne óti pos ékhi the-Cairo.NOM.N. say.3PL.PREs.IND. THAT THAT ${ }_{2}$ has rúghes dhekatéseris khiliádhes streets-fourteen thousand.ACC.F. '(People) say that Cairo has fourteen thousand streets.' (Anthology: 115)

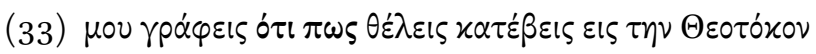
mu ghráfis óti pos thélis katévis is me.GEN. write.2Sg. THAT THAT 2 will-get-down.2SG.FUT.IND. to tin Theotókon the God's Mother.Acc. 'You are writing to me that you are going to go to Theotokos' church.' (Anthology: 234)

38 Although it is difficult to provide a measure of the degree of acceptability (cf. Lyons 1968: $137 \mathrm{ff}$.) of all three structures, the óti + na clauses are traceable in MG. Indeed, a Google search of the phrase $\varepsilon i \pi \varepsilon$ ó $\tau$ v va ípe óti na '(she/she) said that' yields several examples from the contemporary $\mathrm{MG}$ language; cf. e.g. a case in which ót $i$ introduces direct

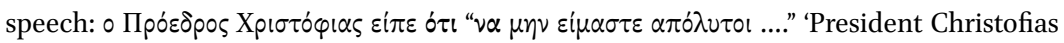
said we should not be stiff ...' (In: http://tinyurl.com/h6ghsju, accessible at 15.12.2015; Office of Press and Information-Republic of Cyprus). Also in reported speech: $\eta \mu \alpha \mu \dot{\alpha}$

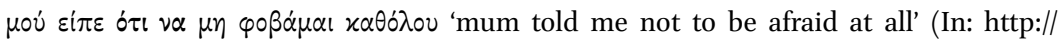
staxtes.com/2003/? $\mathrm{p}=7688$, accessible at 15.12 .2015$)$. We still believe that these cases are ungrammatical in SMG but obviously they may be acceptable under certain contextual conditions (e.g. after verba dicendi but not after directives). More research on this topic is needed. 


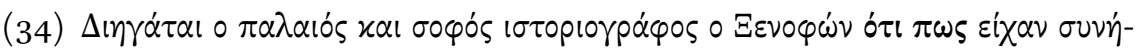

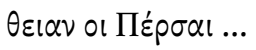

Dhiigháte opaleós ke

narrate.3SG.PRES.IND. the-ancient and

sofós istorioghráfos oXenophon óti pos íkhan

wise-historiographer-the-Xenophon.NOM. THAт THAT ${ }_{2}$ had.3PL.

sinithia oi Pérse

custom.ACC.SG.F. the-Persians.NOM.M.

'Xenophon reports that there was a custom among the Persians ....' (Anthology: 45)

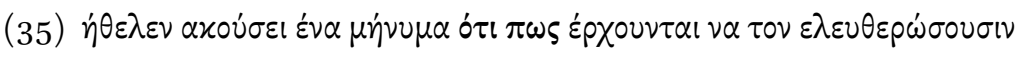

ithelen akúsi énamínima óti pos

would.3SG. listen.INF. one-message.ACC.SG.N. THAT THAT ${ }_{2}$

érkhunde $\quad \boldsymbol{n a}$ ton eleftherósun

come.3PL.PRES.IND. M.PRT him liberate.3PL.(+perf)

'(He) would hear a message that they were coming to set him free.' (Anthology: 45)

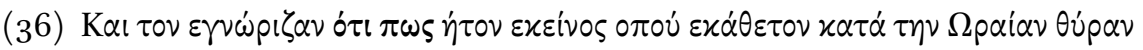

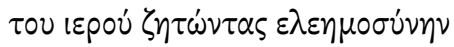

ke ton eghnórizan óti pos iton ekínos

and him know.3PL.IND.IPF. THAT THAT 2 was that.DEMPR.3SG.M

ópu ekátheton katá tin oréan thíran

who (lit. < where) sit.3PL.IND.IPF. at the-beautiful-door.ACC.SG.F.

tu ierú zitóndas eleimosínin

the-temple.GEN. ask.CONV. alms.ACC.SG.F.

'They knew that he was the man who used to sit and beg at the Beautiful Gate of the Temple.' (Anthology: 20)

In accordance with the selecting predicates, we observe that the óti + pos clauses occur in "narrative" contexts with reference to events to which the speaker or the subject of the predicate of the main clause has 'non-firsthand' knowledge (other terms: 'non-confirmative', 'indirective', and 'mediative', cf. Aikhenvald 2004: 25). On these grounds, it may be suggested that most óti + pos clauses encode a certain degree of evidentiality. Despite the fact that evidentiality is chiefly associated with a verbal category or it is expressed with particles, there is no reason to exclude the possibility for a language to manifest evidentiality in the domain of a Complementiser Phrase 
(CP). ${ }^{39}$ As Aikhenvald (ibid.: 69) puts it, "there are hardly any morphological limitations on how evidentiality can be expressed".

Syntactically, in turn, it may be rather erroneous to postulate a univerbation of the two conjunctions. Although a univerbation in the head of a CP is possible

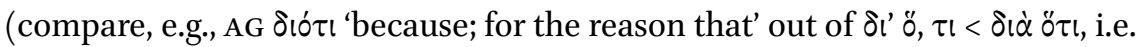
from a configuration of preposition + neutral relative pronoun, cf. Schwyzer \& Derbrunner 1950: 661), a univerbation of two complementisers should have been difficult at this early stage of emergence of this structure because a grammaticalisation process within phrases normally takes place when two or more lexical items that have a distinct categorical status form a collocation within a particular context (cf. also Hopper \& $\operatorname{Traugott}^{2} 2003: 134$ f.). Since óti and pos shared the same categorical status when they were used separately, a univerbation at the early stage could not be possible (although it could be possible in a later stage, if the structure was well established in the language). It is then preferable to analyse ót $i$ as a sort of a marker analogous to the reported/ indirect speech marker we postulated for the ót $i+n a$ clauses.

Diachronically, óti has had the function of marking reported speech. Most AG verba dicendi would take either ö $\tau \iota$ or $\omega \varsigma$ when they expressed genuine verbal meaning (whereas verba putandi or verbs of thinking for example basically opted for infinitive, cf. Smyth 1920: 449) and could introduce reported or even direct speech (Jannaris 1897:471 f.; Smyth 1920: 584; cf. also Fykias \& Katsikadeli 2013 on a diachronic presentation of indirect speech features in Greek). This pattern is also found in the Koine text of New Testament (NT), in which ótican signalise direct or indirect speech. In its use as a sort of "quotation marks", ${ }^{40} \mathrm{AG}$ and Koine ö $\tau$ is called hoti-recitativum (cf. Blass, Debrunner \& Funk 1961 § 470, and Levinsohn 1999). Compare the example in (37):

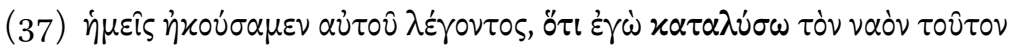
hēmeĩs ēkoúsamen autoũ légontos hóti egò we hear.1PL.AOR.IND. he-saying.Gen. THAT I katalúso tòn naòn toũton destroy.1SG.FUT.IND. the-temple-this.ACC.SG.N. 'We heard him say, I will destroy this temple ...' (Mar. 14:58)

39 Cf. Wiemer 2015 on the "connective" jakoby in Polish that also functions as an evidential complementiser.

40 Cf. Levinsohn (1999: 2): "Grammarians refer to the use of ö $\tau$ in (2b) as "recitativum, when it is practically equivalent to our quotation marks” (Moulton \& Milligan 1974 (1930):463). 
The "pleonastic" óti in EMG does not undertake the function of ö $\tau$ recitativum, since it does not introduce direct speech. Nevertheless, the role of NT ö $\tau$ l as a marker of either direct or indirect speech could well have influenced the ecclesiastical scholars since they constantly dealt with the language of the Bible.

Thus, we can put forward the idea that in the collocation ót $i$ + pos the first element plays an introductory role while the complement clause is an adjunct in apposition. If this analysis holds, the ót $i$ is a constituent of the main clause, quasi an argument, and therefore it is no longer a genuine conjunction, given that its content is less grammatical and more lexical, somehow "returning" to the etymological roots of óti (〈AG ö $\tau$, a neuter relative pronoun). ${ }^{41}$ And so the

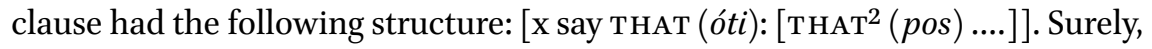
etymology did not play a crucial role here, but the persistent presence of the ö $\iota$ recitativum in the literal tradition of Greek was giving a stylistic model that had an impact up to the EMG. Furthermore, the conjunction pos could convey an evidential reading in this configuration.

\section{3}

\section{Conclusions}

In accordance with the discussion above, we can draw the conclusion that the occurrence of the three "pleonastic" formations that are ungrammatical or only very marginally accepted ${ }^{42}$ in SM G, namely the combinations of the markers ót $i$ $+n a$, pos $+n a$ and $o t i+p o s$, followed a semantic and syntactic rationale, in spite of the asymmetries that are attested in their usage as a result of their distinct function in different authors, dialects or genres. Summing up:

a. The ót $i+n a$ configuration is the most preponderant within our corpus. In the text of the Corfiot Kartanos, the ót $i n a$ appears in a systematic fashion after particular sets of predicates and in a certain syntactic role.

b. The formation pos $+n a$ is less frequent altogether, but it is the only "pleonastic" one with the mood particle $n a$ found in the Cretan Morezinos. This provides strong evidence that a dialectic differentiation underlies the distribution of óti and pos (óti is very rare in Morezinos anyway since it appears only in 25 cases, also along with pos, while pos is attested 764 times).

\footnotetext{
41 Cf. Kiparsky 1995 for a parallel development in Germanic languages and Roberts \& Roussou 2003:110 ff. for English that.

42 That concerns only ót $i+n a$, as we discussed in footnote 38 .
} 
c. Though it is difficult to indicate an initial context in which the óti $+n a$ and pos + na structures arose, we may hypothesize that in cases in which the meaning of $n a$ was not purely modal but also leant towards futurity, the complementiser ót $i$ became compatible with $n a$ in the same way it can co-occur in SMG with the future particle tha. In later phases, óti assumed a more generic syntactic role, being compatible not only with assertions but also with modal expressions. In certain varieties, especially in Western Greek dialects, óti $+n a$ is selected extensively by directive verbs, encoding an embedded indirect nonassertive mood (mostly an imperative) and marking the distinction between the matrix and the embedded subject.

d. The marker ót $i$ both in the óti $+n a$ and the ót $i+p o s$ conjunctions can be described as a marker introducing indirect speech. This is fairly straightforward after, for example, verbs of saying or verbs of order that select ót $i+$ $n a$, or verbs of narration and perception that select óti + pos, but it can also be argued for other categories of predicates, such as volitionals. This role of óti is reminiscent of the ö $\tau$ r recitativum of New Testament, the influence of which might have played a role. Nevertheless, in terms of syntax ót $i$ must have had a different position and function in these two constructions. In óti $+n a$ complements, óti is probably a complementiser, whereas $n a$ forms a cluster with the verb as in MG. In coordinating clauses óti should not be repeated, contrary to $n a$ which is obligatory before a verb in these clauses. The case of $o$ t $i+$ pos is more obscure. Given the scarcity of the examples, it is difficult to postulate a univerbation of the two markers or a duplicate complementiser. Our (tentative) analysis is that semantically ót $i$ introduces the indirect speech while pos is somehow associated with evidentiality in this particular constellation. Syntactically, ót $i$ may be interpreted as an argument-like element, and the pos-clause is an adjunct in apposition to this óti. That both óti and pos were to a great extent used as complementisers in complementary distribution explains why this construction did not get established in the language.

A number of issues, such as a more precise syntactic analysis of these structures, the dialectic differentiation concerning them on the basis of the available EMG texts and a systematic comparison with earlier phases of Greek, as well as with other languages with which EMG was in contact, are objects of ongoing research. 


\section{References}

Aikhenvald, Alexandra Y. 2004. Evidentiality. Oxford: Oxford University Press.

Alboiu, Gabriela. 2004. "Shared arguments in control". Toronto Working Papers in Linguistics 22, 53-74.

Auroux, Sylvain. 1994. La révolution technologique de la grammatisation. Liège: Mardaga.

Austin, John. ${ }^{2}$ 1975. How to Do Things with Words. Cambridge: Cambridge University Press.

Baggioni, Daniel. 1997. Langues et nations en Europe. Paris: Payot.

Blass, Friedrich, Albert Debrunner and Robert W. Funk. 1961. A Greek Grammar of the New Testament. Chicago: University of Chicago Press.

Dobrovie-Sorin, Carmen. 1994. The Syntax of Romanian: Comparative Studies in Romance. Berlin / New York: Mouton de Gruyter.

Fischer, Olga. 2007. Morphosyntactic Change. Functional and Formal Perspectives. Oxford: Oxford University Press.

Fykias, Ioannis and Christina Katsikadeli. 2013. "The rise of 'subordination features' in the history of Greek and their decline: The 'indirect speech traits cycle'”. Journal of Historical Linguistics 3:1, 28-48.

Haspelmath, Martin. 1995. "The converb as a cross-linguistically valid category". In Haspelmath \& König 1995, 1-56.

Haspelmath, Martin and Ekkehard König (eds.). 1995. Converbs in Cross-Linguistic Perspective. Structure and Meaning of Adverbial Verb Forms: Adverbial Participles, Gerunds. Berlin / New York: Mouton de Gruyter.

Hesse, Rolf. ${ }^{2} 2003$. Syntax of the Modern Greek Verbal System, the Use of the Forms, Particularly in Combination with $\theta \alpha$ and $v \alpha$. Copenhagen: Museum Tusculanum Press.

Holton, David, Peter Mackridge and Irene Philippaki-Warburton. 2012. Greek: A Comprehensive Grammar. 2nd ed. revised by Vassilios Spyropoulos. London and New York: Routledge.

Hopper, Paul. 1987. "Emergent grammar". In Berkeley Linguistics Society 13: General Session and Parasession on Grammar and Cognition, Jon Aske, Natasha Berry, Laura Michaelis and Hana Filip (eds), 139-157. Berkeley: Linguistics Society.

Hopper, Paul and Elizabeth Closs Traugott. ${ }^{2} 2003$. Grammaticalization. Cambridge: Cambridge University Press.

Horrocks, Geoffrey. 2010. Greek: A History of the Language and its Speakers. 2nd ed. Wiley-Blackwell.

Jeffreys, Elizabeth (ed.). 1998. Digenis Akritis: The Grottaferrata and Escorial Versions. Cambridge: Cambridge University Press.

Jeffreys, Michael. 1996. "The silent Millennium. Thought on the evidence for spoken 
Greek between the last papyri and Cretan Drama". In $\Phi ا \lambda \varepsilon \dot{\varepsilon} \lambda \eta \eta \nu$. Studies in Honour of Robert Browning, C.N. Constantinides (ed.), 133-149. Venice: Istituto ellenico di studi bizantini e neoellenici.

Joseph, Brian D. 1983. The Synchrony and Diachrony of the Balkan Infinitive. A Study in Areal, General, and Historical Linguistics. Cambridge: Cambridge University Press.

Kakoulidi-Panou, Eleni (ed.). 200o. Ioannikios Kartanos. Palaia te kai Nea Diathiki (Venice 1536) [in Greek]. Thessaloniki: Centre for Greek Language.

Kakoulidi-Panou, Eleni, Eleni Karantzola and Maria Chalvatzidaki (eds). 2007. Ioannis Morezinos. Klini Solomontos (1599) [in Greek]. Iraklio: Etairia Kritikon Istorikon Meleton.

Kakoulidi-Panou, Eleni, Eleni Karantzola and Katerina Tiktopoulou (in press). Demotic Prose Texts of the 16th c. [in Greek]. Thessaloniki and Athens: Centre for Greek Language and MIET.

Kapsomenos, S.G. 1968. Zur Häufung Synonymer Partikeln in der spätgriechischen Volksprache. In Polychordia: Festschrift Franz Dölger zum 75. Geburtstag, P. Wirth (Hrsg.), 3: 134-140. Amsterdam: Adolf M. Hakkert.

Karantzola, Eleni. 2000. "Linguistic afterword. Commentaries on the language of the text” [in Greek]. In Kakoulidi-Panou 2000, 503-548.

Karantzola, Eleni. 2006. "Sur la langue "populaire" de la Grèce ottomane et vénitienne". Revue des études néohelléniques 2 (n.s.), 107-122.

Kiparsky, Paul. 1995. "The Indo-European origins of Germanic syntax". In Clause Structure and Language Change, Adrian Battye \& Ian Roberts (eds), 140-170. Oxford: Oxford University Press.

Kroch, Anthony. 1989. "Reflexes of grammar in patterns of language change". Language Variation and Change 1, 199-244.

Landau, Idan. 2004. "The scale of finiteness and the calculus of control". Natural Language and Linguistic Theory 22, 811-877.

Legrand, Emile (ed.) 1870. Nikolaos Sofianos: Grammatiki tis koinis ton Ellinon glossis. Athens.

Levinsohn, Stephen H. 1999. “'O $\tau$ เ Recitativum in John's Gospel: A stylistic or a pragmatic device?" In Work Papers of the Summer Institute of Linguistics, University of North Dakota Session 1999 Volume 43. Online URL: http://www.und.edu/dept/ linguistics/wp/1999Levinsohn.PDF

Lyons, John. 1968. Introduction to Theoretical Linguistics. Cambridge: Cambridge University Press.

Lyons, John. 1977. Semantics. Vol. 2. Cambridge: Cambridge University Press.

Mackridge, Peter. 1985. The Modern Greek Language. A Descriptive Analysis of Standard Modern Greek. Oxford: Oxford University Press.

Manolessou, Io. 2005. "From participles to gerunds". In Advances in Greek Generative Syntax, Melita Stavrou and Arhonto Terzi (eds.) 241-284. Amsterdam and Philadelphia: John Benjamins. 
Markopoulos, Theodore. 2007. "Categorial features and grammaticalization: the case

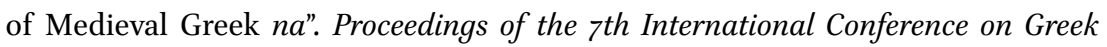
Linguistics.

Markopoulos, Theodore. 2009. The Future in Greek. From Ancient to Medieval. Oxford: Oxford University Press.

Matthews, Peter H. 2005. The Concise Oxford Dictionary of Linguistics. 2nd ed. Oxford: Oxford University Press.

Nicholas, Nick. 1996. "The diachrony of Modern Greek complementiser pos: a nonmonotonic language change". University of Melbourne Working Papers 16, 195-222.

Palmer F.R. 2006. Mood and Modality. 2nd ed. Cambridge: Cambridge University Press.

Philippaki -Warburton, Irene. 1994. "The subjunctive mood and the syntactic status of the particle na in Modern Greek". Folia Linguistica 28, 297-328.

Philippaki-Warburton, Irene and Vassilios Spyropoulos. 2004. "A change of mood: the development of the Greek mood system". Linguistics 42:4, 791-817.

Roussou, Anna. 2006. Complementizers [in Greek]. Athens: Patakis.

Roussou, Anna. 2009. "Complementizers in the Greek dialects". Studies in Greek Linguistics 29, 371-384.

Roberts, Ian \& Anna Roussou. 2003. Syntactic Change: A Minimalist Approach to Grammaticalization. Cambridge: Cambridge University Press.

Sampanis, Konstantinos. 2012. "The Modern Greek subjunctive mood and its semantic features". In Current Trends in Greek Linguistics, Georgia Fragaki, Thanasis Georgakopoulos and Charalambos Themistocleous (eds), 66-91. Cambridge Scholars Publishing.

Schwyzer, Eduard and Albert Debrunner. 1950. Griechische Grammatik (II-Syntax und syntaktische Stilistik). München: Beck.

Smyth, Herbert Weir. 1920. A Greek Grammar for Colleges. American Book Company (Reprints from the collection of the University of Michigan Library).

Terzi, Arhonto. 1992. PRo in finite clauses. A study of the inflectional heads of the Balkan languages. Doctoral Dissertation, The City University of New York.

Tomić, Olga Mišeska (ed.). 2004. Balkan Syntax and Semantics. Amsterdam/Philadelphia: John Benjamins Publishing Company.

Tomić, Olga Mišeska. 20o6. Balkan Sprachbund Morpho-Syntactic Features. Dordrecht: Springer.

Wiemer, Björn. 2015. "An outline of the development of Polish jakoby in 14th-16th century documents (based on dictionaries)". In Studies on Evidentiality Marking in West and South Slavic, Björn Wiemer (ed.), 217-302. München: Verlag Otto Sagner. 